\title{
Tumor-infiltrating lymphocytes in primary tumors of colorectal cancer and their metastases
}

\author{
KATARZYNA JAKUBOWSKA ${ }^{1}$, MARIUSZ KODA ${ }^{2}$, WOJCIECH KISIELEWSKI ${ }^{3}$, \\ LUIZA KAŃCZUGA-KODA $^{1}$ and WALDEMAR FAMULSKI ${ }^{1,3}$ \\ ${ }^{1}$ Department of Pathomorphology, Comprehensive Cancer Center, 15-027 Bialystok; \\ Departments of ${ }^{2}$ General Pathomorphology and ${ }^{3}$ Medical Pathomorphology, \\ Medical University of Bialystok, 15-269 Bialystok, Poland
}

Received November 16, 2017; Accepted October 18, 2018

DOI: $10.3892 / \mathrm{etm} .2019 .8146$

\begin{abstract}
The presence of tumor cells in the large intestine stimulates hypoxia and local inflammatory mediators that activate numerous inflammatory cells, including a diverse lymphoid tumor cell population. The aim of the present study was to evaluate tumor-infiltrating lymphocytes (TILs) located in the invasive primary tumor, surrounding deposits of tumor cells and those present in distal metastatic cells in the liver of patients with colorectal cancer. Furthermore, the correlation of TILs with anatomical parameters was assessed. The study group included 123 patients with primary tumor colorectal cancer without distant metastasis, 25 cases with deposits of colorectal cancer cells and 15 cases of colorectal cancer liver metastasis. TILs were assessed in tissues stained with hematoxylin-eosin using light microscopy and evaluated by two independent pathologists blinded to the clinical information. Infiltration of TILs in the invasive front of primary tumor was stronger compared with those surrounding deposits of cancer cells and liver metastases $(\mathrm{P}<0.001)$. TILs in the invasive front of primary tumor masses were associated with various variables linked with tumor progression and inflammatory cell infiltrate. TILs distributed around the deposits of cancer cells were associated with postoperative treatment; however, those localized in the invasive front of liver metastases were correlated with preoperative therapy. In conclusion, TILs assessment in primary tumors of colorectal cancer, surrounding deposits of tumor cells and in the metastatic cells in the liver may be helpful in understanding the role of these cells in the organization of immune response.
\end{abstract}

Correspondence to: Dr Katarzyna Jakubowska, Department of Pathomorphology, Comprehensive Cancer Center, 12 Ogrodowa Street, 15-027 Bialystok, Poland

E-mail: kathian@wp.pl

Key words: tumor-infiltrating lymphocytes, colorectal cancer liver metastasis, deposits

\section{Introduction}

The immune mechanism of the digestive system is very complex and consists of many synergistic interacting elements. The basis of this mechanism is glandular cells and inflammatory cells. Under normal conditions, inflammatory cells located in the glandular ducts are responsible for the balance in the immune system of the large intestine. Intestinal bacteria stimulate GALT-associated lymphoid tissue. The system consists of lymphocytes located in intestinal lymph nodes (Peyer's tufts), endothelial cells, and in the lamina propria (1).

Cancer cells stimulate hypoxia and local inflammatory mediators that activate numerous inflammatory cells, including a diverse population of lymphoid cells (2). Tumor Associated Antigens (TAA) are recognized and presented by the so-called antigen presenting cells (APCs) which MHC class II molecules on their surface. They include tumor-infiltrating lymphocytes (TILs) with phenotypes B and Th (3). In addition, tumor antigens can be bound by $\mathrm{CD}^{+} \mathrm{T}$ lymphocytes with MHC class I molecules (4). The heterogeneous density of tumor infiltrating immune cells was observed according to tumor location (5). Kwak et al (5) showed that $\mathrm{CD}^{+}$positive lymphocytes was the highest in invasive margin compare to those in the tumor center and distant metastasis. Moreover, authors confirmed a low density of $\mathrm{CD} 8^{+} \mathrm{TILs}$ in center of tumor in advanced colorectal cancer.

The tumor cells exhibit high histological and clinical heterogeneity and thus a high variability within the TAA. Decay or change in TAA is conditioned by the selection of clones that consist in submitting tumor cells to the action of an immune response. As a result of elimination, the cells with the highest survival and proliferation are selected. Next, the selected clones of altered antigenicity proliferate in an uncontrolled manner and condition further invasion of tumors to nearby tissues and distant organs (6). In colorectal cancer, metastatic spread of cancer was located mainly in the liver and lungs. Firstly, disseminating CRC cells come into portal circulation, then they situated in the liver parenchyma due to vessel fenestration. On the other hand, CRC cells can get into general circulation and lead to development of pulmonary metastases (7). Free antigens or fragments of their cell membranes inhibit co-stimulatory molecules on APC cells and block cytotoxic T lymphocyte activity by CLTA-4 (8). In addition, 
tumor cells may have numerous Fas (FasL) ligands on their surface that bind to its receptor on the surface of cytotoxic $\mathrm{T}$ lymphocytes. This leads to the death of these inflammatory cells and the elimination of an important element of the immune response (9). Therefore, immunotheraphies that aim to stimulate immune response have been successfully used in many malignant tumors such prostate cancer and malignant melanoma (7).

Therefore, it seems reasonable to assess the activity of the immune system in tissue material, in the form of TILs located in the invasive primary tumor front as well as those surrounding tumor cell deposits and in distal metastases to the liver in patients with colorectal cancer correlated with anatomoclinical parameters.

\section{Materials and methods}

The study was performed in conformity with the Declaration of Helsinki for Human Experimentation and the protocol was approved by the Bioethics Committee of the Medical University of Bialystok (no. R-I-002/352/2016). Written informed consent was obtained from all participants.

Patients. The study group consisted of 163 patients diagnosed with colorectal carcinoma (female-56, male-88) and operated in the Department of Oncological Surgery, in Comprehensive Cancer Center of Bialystok, in years 2014-2016. Patients were divided into 3 groups: i) 123 cases of primary tumor colorectal cancer without distant metastasis, ii) 25 cases with deposits of colorectal cancer cells and iii) 15 cases of colorectal cancer liver metastasis. During routine diagnostics all patients underwent basic diagnostic laboratory tests, ECG, spirometry, arterial blood gasometric test as well X-ray and computerized tomography of the chest. The clinical efficiency was performed with a 5-point scale of Zubroda (WHO) (10). The clinical staging of CRC was evaluated according to TNM classification (11).

Patients diagnosed with neoplasms in rectum received preoperative therapy $(\mathrm{N}=60)$ : Chemotherapy $(\mathrm{N}=9)$, radiotherapy $(\mathrm{N}=39)$ or radio-chemotherapy $(\mathrm{N}=12)$. They were administered a dose of 25 Gy in fractions of 5 Gy during one week in the pelvic area. Preoperatively, patients with tumors localized in a different site received neither inflammatory nor immunosuppressive therapy. Postoperatively, 64 cases received additional therapy: Chemotherapy $(\mathrm{N}=57)$, radiotherapy $(\mathrm{N}=3)$ or radio-chemotherapy $(\mathrm{N}=5)$. The type of pre/postoperative therapy was chosen on the basis of current recommendation for colorectal cancer treatment. The response to preoperative therapy was estimated according to the RECIST (Response Evaluation Criteria in Solid Tumors) criteria (12).

Histopathological examination. Sections, $4 \mu \mathrm{m}$-thick, were cut from paraffin blocks and stained with hematoxylin and eosin (H\&E) (no. cat. 468802128; POCH S.A.). The routine histopathological assessment of the sections referred to type of tumor growth, tumor size, histological type and percentage of the mucinous component, grade of malignancy, pTNM and Duke stages. We also analyzed venous, lymphatic and perineural invasions, characteristic features of lymph node invasion such as number of resected and invaded lymph nodes, presence of micro- and macrometastases, invasion of the pouch lymph node; presence of distant metastases and their size in millimeters. We also assessed the presence of deposits, their number and size in millimeters (13). Tumor deposits (TDs) are defined as focal aggregates of adenocarcinoma located in the pericolic or perirectal fat disassociated with the primary tumor (14). The inflammation infiltrate in both invasive front of the tumor and the center of the main mass was classified according the Klintrup-Makinen criteria (15). A detailed demographic characteristic of patients is shown in Table I.

Analysis of Tumor-Infiltrating Lymphocytes. Tumor-Infiltrating Lymphocytes were assessed in tissue material stained with hematoxylin-eosin and by light microscopy (Leica DM6 B; KAWA.SKA) and evaluated by two independent pathologists blinded to the clinical information. The analyses of TILs were performed in i) the invasive front of primary tumor mass, ii) the areas surrounding deposits of cancer cells and iii) the invasive front of colorectal cancer liver metastasis. TILs were determined as a percentage of mononuclear inflammatory cells over total intratumoral stromal area and counted in 5 HPF (total magnification, x200-400) in the invasive front or areas surrounding the deposits, except for tumor areas with crush artifacts, necrosis or regressive hyalinization $(16,17)$. We defined a lymphocyte as a small, rounded cell a large, dark-staining nucleus with little eosinophilic cytoplasm in diameter no more than $7 \mu \mathrm{m}$. There is the smallest nucleated cell which can be found in colorectal cancer tissue. For statistical analysis, three levels of infiltration in the stroma TILs were determined: 1 weak (0-10\% of stromal TILs), 2-moderate (20-40\% of stromal TILs) and 3-strong (50-90\% of stromal TILs). Also, in order to conduct statistical analysis, we divided study group into: Group 1-(1 level of stromal TILs) and group 2-(2 and 3 levels of stromal TILs).

Statistical analysis. Statistical analysis was conducted using the STATISTICA 10.0 program (Statsoft). $\chi^{2}$ test was used to compare the groups. Correlations between the parameters were calculated by the Spearman's correlation coefficient and $\chi^{2}$ tests. A P-value of $<0.05$ was considered statistically significant.

\section{Results}

Tumor-Infiltrating Lymphocytes in primary tumor, around the deposits and in the invasive front of distant metastases to liver. TILs in the invasive front of primary tumor were weak in 72 cases, moderate in 30 cases and strong in 21 cases. Infiltration of TILs around the deposits of cancer cells was weak in 18 cases, moderate in 4 cases and strong in 3 cases. Patients with distant metastases to liver showed weak infiltration of TILs in 11 cases, moderate in 3 cases and strong in 1 case. The differences between all groups were statistically significant $(\mathrm{P}=0.003)$. The rults are shown in Table II and Fig. 1.

Correlations between TILs in the invasive front of primary tumor mass and anatomoclinical features. TILs in the invasive front of primary tumor mass were negatively correlated with venous, lymphatic and perineutral invasions $(\mathrm{R}=-0.321$; $\mathrm{P}=0.009 ; \mathrm{R}=-0.434, \mathrm{P}=0.004 ; \mathrm{R}-0.197, \mathrm{P}=0.013)$, lymph node 
Table I. Demographic details of the study groups.

\begin{tabular}{lccc}
\hline & Primary tumor & Deposits of cancer & Liver metastases \\
Variables & $(\mathrm{N}=123)(\%)$ & cells $(\mathrm{N}=25)(\%)$ & $(\mathrm{N}=15)(\%)$ \\
\hline
\end{tabular}

Age (years)

$<60$

$>60$

$29(23.7)$

$6(24)$

$19(76)$

$1(6.6)$

$94(76.3)$

$75(61.0)$

$13(10.5)$

$5(4.0)$

$4(3.2)$

$15(60)$

$80(65.0)$

103 (83.7)

20 (16.3)

20 (80)

$20(16.3)$

81 (65.8)

22 (17.9)

$17(13.8)$

$43(34.9)$

58 (47.1)

$2(4.2)$

$20(80)$

$21(84)$

24 (96)

58 (47.2)

123 (100)

0 (0)

$21(84)$

0 (0)

0 (0)

0 (0)

0 (0)

$25(100)$

0 (0)

40 (32.6)

83 (67.4)

18 (72)

29 (70)

6 (16)

13 (26)

17 (24)
$10(40)$

15 (60)

3 (12)

1 (4)

1 (4)

5 (20)

5 (20)

3 (12)

2 (8)

$0(0)$

0 (0)

4 (16)

1 (4)

4 (16)

3 (75)

1 (25)

$1(33.3)$

2 (66.7)

0 (0)

7 (28)

2 (28.5)

1 (14.2)

4 (57.3)

14 (93.4)

$5(33.3)$

$10(66.7)$

2 (13.3)

1 (6.6)

2 (13.3)

$1(6.6)$

$9(60.2)$

13 (98.7)

2 (1.3)

2 (1.3)

13 (98.7)

0 (0)

0 (0)

0 (0)

0 (0)

15 (100)

6 (39.8)

9 (60.2)

$0(0)$

15 (100)

8 (53.4)

7 (46.6)

7 (46.6)

8 (53.4)

$11(63.7)$

4 (36.3)

3 (2)

12 (80)

0 (0)

3 (100)

0 (0)

3 (60)

2 (66.7)

1 (33.3)

2 (40)
PR 
Table I. Continued.

\begin{tabular}{lccc}
\hline Variables & $\begin{array}{c}\text { Primary tumor } \\
(\mathrm{N}=123)(\%)\end{array}$ & $\begin{array}{c}\text { Deposits of cancer } \\
\text { cells }(\mathrm{N}=25)(\%)\end{array}$ & $\begin{array}{c}\text { Liver metastases } \\
(\mathrm{N}=15)(\%)\end{array}$ \\
\hline $\begin{array}{l}\text { Postoperative treatment } \\
\text { Yes }\end{array}$ & $46(37.3)$ & $5(20)$ & $8(53.4)$ \\
No & $77(62.7)$ & $20(80)$ & $7(46.6)$ \\
Type of postoperative treatment & & & $6(75)$ \\
CHT & $40(86.9)$ & $5(100)$ & $1(12.5)$ \\
RHT & $2(4.5)$ & $0(0)$ & $1(12.5)$ \\
RHT+CHT & $4(8.6)$ & $0(0)$ & $6(40)$ \\
Disease-free survival & & & $3(20)$ \\
$<6$ months & $38(30.8)$ & $9(36)$ & $6(40)$ \\
6-12 months & $27(22.9)$ & $5(20)$ & $11(44)$ \\
$>12$ months & $57(46.3)$ & & \\
\hline
\end{tabular}

RHT, radiotherapy; CHT, chemotherapy; SD, stable disease; PR, progression of disease.

Table II. Distribution of TILs.

\begin{tabular}{|c|c|c|c|c|c|}
\hline TIL location & $\mathrm{N}$ & $\begin{array}{c}\text { Weak levels } \\
\text { of TILs }\end{array}$ & $\begin{array}{c}\text { Moderate } \\
\text { levels of TILs }\end{array}$ & $\begin{array}{c}\text { Strong } \\
\text { levels of TILs }\end{array}$ & P-value \\
\hline Invasive front of primary tumor & 123 & 72 & 30 & 21 & 0.003 \\
\hline Deposits of cancer cells & 25 & 18 & 4 & 3 & \\
\hline Invasive front of distant metastasis to liver & 15 & 11 & 3 & 1 & \\
\hline
\end{tabular}

$\chi^{2}$ test. TILs, tumor-infiltrating lymphocytes.

metastases, their number and invasion of pouch $(\mathrm{R}=-0.197$, $\mathrm{P}=0.019 ; \mathrm{R}=-0.358, \mathrm{P}=0.004 ; \mathrm{R}=-0.419, \mathrm{P}=0.030)$.

Correlation between TILs localized in areas around the deposits of cancer cells and in the invasive front of distant metastases to liver and anatomoclinical variables. TILs distributed around the deposits of cancer cells were associated with postoperative treatment $(\mathrm{R}=0.452 ; \mathrm{P}=0.017)$ and stronger inflammatory cell infiltrate in the invasive front of tumor $(\mathrm{R}=0.439, \mathrm{P}=0.040)$. TILs localized in the invasive front of liver metastases were positively correlated with preoperative treatment $(\mathrm{R}=0.559, \mathrm{P}=0.030)$, $\mathrm{pT}$ stage $(\mathrm{R}=0.554, \mathrm{P}=0.003)$ and inflammatory cell infiltrate in the invasive front of primary tumor $(\mathrm{R}=0.664, \mathrm{P}=0.017)$. Moreover, TILs of liver metastases were negatively associated with lymph node metastases $(\mathrm{R}=-0.686, \mathrm{P}=0.004)$ and presence of tumor deposits $(\mathrm{R}=-0.543, \mathrm{P}=0.036)$ (Tables III and IV).

\section{Discussion}

Lymphocytic infiltration is a major immunological defense against tumor cells in solid tumors and is a potential predictor of colorectal cancer (18-20). In our studies, we found a weak infiltration in 72 cases, moderate in 30 cases and strong in 21 cases. TILs may be stimulated by APC-lymphocytes, while the degree and direction of activation and selectivity of stromal TILs are dependent on the type of antigen on the tumor cell (21). TILs located in the invasive front are one of the first elements of host defense against invasive tumor cells that further stimulate or inhibit cellular response (22). In brief, there are correlations in which we observed invasions of tumor cells into blood vessels and lymph vessels, as well as perineutral space with a decrease in the amount of TILs. In addition, in patients with a low incidence of TILs in the invasive primary tumor front, we found metastases to the local lymph nodes and tumor invasion beyond the nodule to the surrounding tissues. The results of our study are consistent with the observations of Perez et al (18), Huh et al (23) and Pagès et al (24,25). Also, Mlecnik et al (26) confirmed that the decrease in intratumoral immune T-cell densities correlated with the growth of the primary tumor and the metastatic spread of colorectal cancer cells. In our studies, we reported a significantly higher TILs infiltration in the primary tumor compared to their presence in the deposits and metastatic carcinoma of the intestinal carcinoma. The failure of TILs in subsequent stages of tumor invasion can be determined by several factors. It has been reported that TILs in colorectal cancer can undergo apoptosis (19). The phenotype of the lymphocytes which commonly contains Treg lymphocytes exerts a significant influence on the organization of TILs and its effectiveness (27). The status of microsatellite instability is 


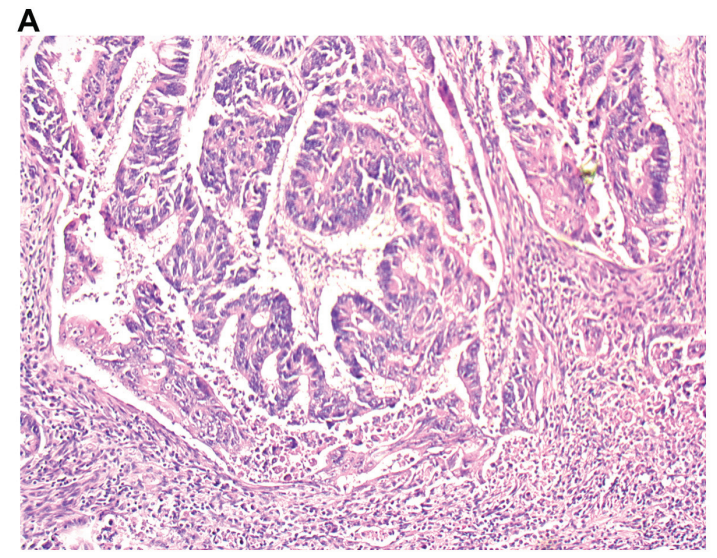

B
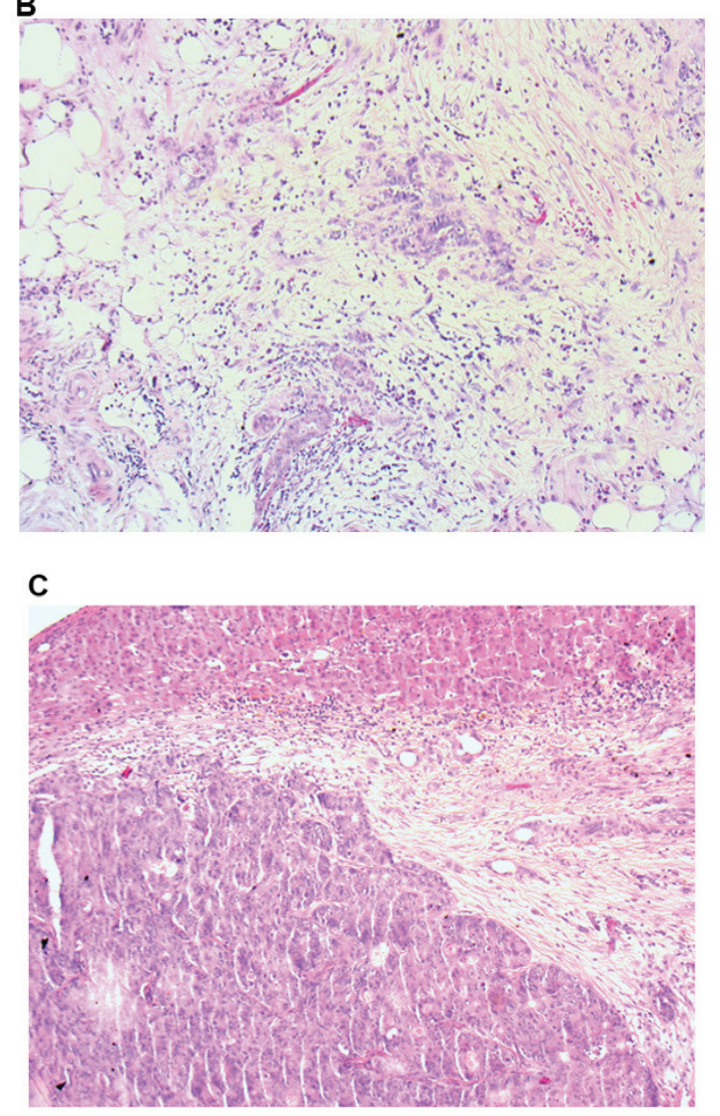

Figure 1. Distribution of TILs. TIL distribution was observed (A) in the invasive front of primary tumor (strong cell infiltrate), (B) those surrounding deposits of cancer cells (weak cell infiltrate) and (C) in the invasive front of distant metastatic cells in the liver (weak cell infiltrate). Evaluation of TILs was performed using hematoxylin and eosin-stained sections. Magnification, x200 in (A and C) and x200 in (B) TILs, tumor-infiltrating lymphocytes.

not trivial. It has been shown that TILs of MSI-H colorectal cancers may be more immunoactive and cytotoxic than in MSS tumors $(28,29)$.

Cancer cells of primary tumors acquire an invasive phenotype and show features of metastasis (30). In the first place, the involvement of blood vessels and lymph nodes, regional lymph nodes and tumor cells crossing the border of the nodule are demonstrated. In some cases, patients with colorectal cancer show deposits of cancer cells (TDs) that are defined and classified as a feature N1C in the 7th edition of the AJCC/TNM staging system (31). There are tumor cells in the pericolorectal or adjacent mesocolic fats far away from the leading edge of the tumor. There should be no exclusion of residual lymph node tissue. Moreover, tumor deposits should be within the lymph drainage area of the primary carcinoma (31). It has been shown that the presence of colorectal cancer deposits may be an unfavorable predictor (31). To our knowledge, this was the first study to investigate the TILs surrounded by tumor deposits. We have mainly reported weak TILs in most cases. The infiltrate of TILs around cancer deposits positively correlated with postoperative treatment in the form of chemo or radiotherapy. Previous studies confirmed that the presence of deposits in patients with rectal cancer who underwent preoperative chemoradiotherapy was associated with a trend of higher local recurrence rate and significantly decreased survival $(32,33)$. The analysis of patients with rectal cancer who underwent preoperative radiotherapy treatment showed the relevance of TDs with several aggressive tumor features, including more intensive regional lymph nodes metastasis and more perineural invasion (34). Perhaps the preoperative treatment modifies the immune response around the deposits, probably into a poor TIL response, which results in the fact that they are an exponent of disease progression. There is also a possibility that it is the selected clones of tumor cells that build deposits escaping from the control of local inflammatory response and directly inhibit its organization, which is also expressed by the presence of a few cells. Therefore, perhaps the increase in the number of TILs around the deposit improves the effect of postoperative treatment. A limitation of our analysis in this case is the fact that the group of patients is not great and the study included neither a detailed breakdown of the deposits of patients with preoperative therapy used nor assessment of its effectiveness. In the future, we will expand our TILs analysis based on these criteria.

With the progression of cancer disease, tumor cells of the subsequent tissue structures, including the distal organs, can be observed. In our studies, we have shown a weak infiltrate of TILs in the invasive front of liver metastatic sites in approximately $73 \%$ of cases. In turn, Kwak et al (5) and Lee et al (35) have observed that higher densities of $\mathrm{CD}^{+}, \mathrm{CD}^{+}$and CD45RO (+) TILs in distant metastases of colorectal cancer were significantly correlated with better prognosis. In contrast to the above studies, Schweiger et al (36) demonstrated that patients with pulmonary metastases from colorectal cancer have a high density of FOXP3 + TILs at invasive front and low density of CD8+ cells in TILs may have worse prognosis. In our studies, we have found correlations between TILs in the invasive frontal metastases of liver cancer and the use of preoperative treatment. Halama et al (37), showed that TIL densities at the invasive margin of liver metastases allowed the prediction of response to chemotherapy with a high sensitivity and specificity. Also Morris et al (38) TILs in patients treated with 5-fluorouracil-based chemotherapy were associated with significantly improved survival. There are indications that the presence of TILs in distant metastases may be conditioned and modified by both pre- and postoperative treatment.

In conclusion, the results of our study confirmed that the histopathological evaluation of TILs infiltration in both the primary tumor of colon cancer and its metastases in the form of deposits and cancer focus of liver may help to determine the extent of immune defense activation and provide a potential pathological outcome. 
Table III. Correlation between TILs in invasive primary tumor front, tumor cell deposits, and distant metastasis to liver and anatomoclinicaal parameters in patients with colorectal cancer.

\begin{tabular}{|c|c|c|c|c|c|c|c|c|c|}
\hline \multirow[b]{2}{*}{ Variable } & \multicolumn{3}{|c|}{$\begin{array}{c}\text { TILs associated } \\
\text { with invasive front of } \\
\text { primary tumor }(\mathrm{N}=123)\end{array}$} & \multicolumn{3}{|c|}{$\begin{array}{c}\text { TILs associated } \\
\text { with deposits of } \\
\text { cancer cells }(\mathrm{N}=25)\end{array}$} & \multicolumn{3}{|c|}{$\begin{array}{c}\text { TILs associated with } \\
\text { invasive front of distant } \\
\text { metastastic cells in liver }(\mathrm{N}=15)\end{array}$} \\
\hline & $\begin{array}{c}\text { Low } \\
\text { group }(\%)\end{array}$ & $\begin{array}{c}\text { High } \\
\text { group }(\%)\end{array}$ & P-value & $\begin{array}{c}\text { Low } \\
\text { group }(\%)\end{array}$ & $\begin{array}{c}\text { High } \\
\text { group }(\%)\end{array}$ & P-value & $\begin{array}{c}\text { Low } \\
\text { group }(\%)\end{array}$ & $\begin{array}{c}\text { High } \\
\text { group }(\%)\end{array}$ & P-value \\
\hline \multicolumn{10}{|l|}{ Age } \\
\hline$<60$ & $20(16.2)$ & $9(7.3)$ & NS & $3(12.0)$ & $3(12.0)$ & NS & $1(6.6)$ & $0(0)$ & NS \\
\hline$>60$ & $42(38.2)$ & $42(38.2)$ & & $15(60)$ & $4(16)$ & & $10(66.6)$ & $4(26.6)$ & \\
\hline \multicolumn{10}{|l|}{ Sex } \\
\hline Female & $24(19.5)$ & $24(19.5)$ & NS & $8(40)$ & $2(8)$ & & $2(13.3)$ & $3(20.0)$ & NS \\
\hline Male & $48(39.1)$ & $27(21.9)$ & & $10(60)$ & $5(22)$ & NS & $9(60.1)$ & 1(6.66) & \\
\hline \multicolumn{10}{|l|}{ Localization } \\
\hline Right-side & $10(8.3)$ & $3(2.4)$ & NS & $1(6.6)$ & $2(8)$ & NS & $1(6.66)$ & $0(0)$ & \\
\hline Transverse & $3(2.4)$ & $2(1.6)$ & & $1(6.6)$ & $0(0)$ & & $6(40.0)$ & $2(13.3)$ & \\
\hline Left-side & $4(3.2)$ & $0(0)$ & & $1(6.6)$ & $0(0)$ & & $1(6.66)$ & $1(6.66)$ & \\
\hline Sigmoid & $10(8.3)$ & $11(8.9)$ & & $14(56)$ & $4(16)$ & & $1(6.66)$ & $1(6.66)$ & \\
\hline Rectum & $44(35.7)$ & $36(29.2)$ & & $5(20)$ & $1(6.6)$ & & $2(13.3)$ & $0(0)$ & \\
\hline \multicolumn{10}{|l|}{ Tumor growth } \\
\hline Expanding & $60(49)$ & $44(35.7)$ & NS & $15(80)$ & $5(22)$ & NS & $10(66.6)$ & $3(20.0)$ & NS \\
\hline Infiltrate & $12(9.7)$ & $7(5.6)$ & & $3(12.0)$ & $2(8)$ & & $1(6.66)$ & $1(6.66)$ & \\
\hline \multicolumn{10}{|l|}{ Tumor size } \\
\hline$<2.5 \mathrm{~cm}$ & $18(14.6)$ & $6(4.8)$ & NS & $2(8)$ & $1(6.6)$ & NS & $1(13.3)$ & $1(6.66)$ & NS \\
\hline $2.5-5.0 \mathrm{~cm}$ & $41(33.6)$ & $34(27.6)$ & & $14(80)$ & $6(21.4)$ & & $10(86.7)$ & $3(20.0)$ & \\
\hline$>5.0 \mathrm{~cm}$ & $13(10.5)$ & $11(8.9)$ & & $2(8)$ & $0(0)$ & & & & \\
\hline \multicolumn{10}{|l|}{ TNM stage } \\
\hline 1 & $23(18.6)$ & $20(16.2)$ & NS & $0(0)$ & $0(0)$ & NS & $0(0)$ & $0(0)$ & NS \\
\hline 2 & $20(16.2)$ & $11(8.9)$ & & $0(0)$ & $0(0)$ & & $0(0)$ & $0(0)$ & \\
\hline 3 & $7(5.6)$ & $5(4)$ & & $2(8)$ & $3(12.0)$ & & $0(0)$ & $0(0)$ & \\
\hline 4 & $2(1.6)$ & $15(12.1)$ & & $17(80)$ & $4(16)$ & & $11(73.4)$ & 4 & \\
\hline \multicolumn{10}{|l|}{ Duke stage } \\
\hline A & $39(31.7)$ & $25(20.3)$ & NS & $0(0)$ & $0(0)$ & NS & $0(0)$ & $0(0)$ & NS \\
\hline B & $34(27.6)$ & $8(6.5)$ & & $5(28)$ & $2(8)$ & & $0(0)$ & $0(0)$ & \\
\hline $\mathrm{C}$ & $11(8.9)$ & $5(4)$ & & $12(60)$ & $3(12.0)$ & & $1(6.66)$ & $0(0)$ & \\
\hline $\mathrm{D}$ & $39(31.7)$ & $13(10.5)$ & & $1(12)$ & $2(8)$ & & $10(93.33)$ & $3(20.0)$ & \\
\hline \multicolumn{10}{|c|}{ Adenocarcinoma type } \\
\hline Partim mucnous & $55(44.7)$ & $48(39.1)$ & & $6(21.4)$ & $2(8)$ & NS & $2(13.3)$ & $0(0)$ & NS \\
\hline Nonmucinous & $17(13.8)$ & $3(2.4)$ & NS & $12(48)$ & $5(22.6)$ & & $9(60.1)$ & $4(26.6)$ & \\
\hline \multicolumn{10}{|c|}{ Grade of malignancies } \\
\hline 2 & $68(53.8)$ & $49(39.8)$ & NS & $16(64)$ & $7(28)$ & NS & $11(73.4)$ & $4(26.6)$ & NS \\
\hline 3 & $4(4.8)$ & $2(1.6)$ & & $2(8)$ & $0(0)$ & & $0(0)$ & 0 & \\
\hline \multicolumn{10}{|c|}{ Preoperative treatment } \\
\hline Yes & $14(11.3)$ & $12(9.7)$ & NS & $2(8)$ & $1(6.6)$ & NS & $0(0)$ & $0(0)$ & 0.037 \\
\hline No & $67(57.8)$ & $30(21.2)$ & & $16(64)$ & $6(21.4)$ & & $11(73.4)$ & $4(26.6)$ & \\
\hline \multicolumn{10}{|c|}{ Postoperative treatment } \\
\hline Yes & $21(19.5)$ & $15(12.1)$ & NS & $8(48)$ & $4(16)$ & 0.018 & $4(26.6)$ & $2(13.3)$ & NS \\
\hline No & $51(41.6)$ & $36(29.2)$ & & $10(52)$ & $3(12.0)$ & & $7(46.8)$ & $2(13.3)$ & \\
\hline
\end{tabular}

NS, not statistically significant; TILs, tumor infiltrating lymphocytes. 
Table IV. Correlation between TILs in invasive primary tumor front, tumor cell deposits, and distant metastasis to liver and parameters of disease progression in patients with colorectal cancer.

\begin{tabular}{|c|c|c|c|c|c|c|c|c|c|}
\hline \multirow[b]{2}{*}{ Variables } & \multicolumn{3}{|c|}{$\begin{array}{c}\text { TILs associated } \\
\text { with the invasive front } \\
\text { of primary tumor }(\mathrm{N}=123)\end{array}$} & \multicolumn{3}{|c|}{$\begin{array}{c}\text { TILs associated } \\
\text { with the deposits of } \\
\text { cancer cells }(\mathrm{N}=25)\end{array}$} & \multicolumn{3}{|c|}{$\begin{array}{l}\text { TILs associated with the } \\
\text { invasive front of distant } \\
\text { metastasis to liver }(\mathrm{N}=15)\end{array}$} \\
\hline & Low $(\%)$ & High $(\%)$ & P-value & Low $(\%)$ & High (\%) & P-value & Low $(\%)$ & High $(\%)$ & P-value \\
\hline \multicolumn{10}{|l|}{ pT stage } \\
\hline 1 & $2(1.6)$ & $1(0.8)$ & NS & $0(0)$ & $0(0)$ & NS & $0(0)$ & $0(0)$ & 0.004 \\
\hline 2 & $31(25.2)$ & $23(18.6)$ & & $6(24)$ & $3(12.0)$ & & $1(6.6)$ & $0(0)$ & \\
\hline 3 & $38(31.1)$ & $27(21.9)$ & & $12(45,4)$ & $3(12.0)$ & & $9(60)$ & $3(20.0)$ & \\
\hline 4 & $1(0.8)$ & $0(0)$ & & $1(6.6)$ & $0(0)$ & & $1(6.6)$ & $1(6.6)$ & \\
\hline \multicolumn{10}{|c|}{ Venous invasion } \\
\hline Absent & $51(41.6)$ & $39(31.7)$ & 0.012 & $10(40)$ & $4(16)$ & NS & $4(60)$ & $2(13.3)$ & NS \\
\hline Present & $21(17)$ & $12(9.7)$ & & $8(32)$ & $3(12.0)$ & & $7(40)$ & $2(13.3)$ & \\
\hline \multicolumn{10}{|c|}{ Lymphatic invasion } \\
\hline Absent & $58(60.3)$ & $39(31.7)$ & 0.009 & $13(38)$ & $2(8)$ & NS & $6(66.6)$ & $4(26.6)$ & NS \\
\hline Present & $26(21.2)$ & $12(9.7)$ & & $5(22)$ & $5(22)$ & & $5(33.6)$ & $0(0)$ & \\
\hline \multicolumn{10}{|c|}{ Perineural invasion } \\
\hline Absent & $65(52.9)$ & $48(39.1)$ & 0.017 & $15(57.4)$ & $6(24)$ & NS & $10(93.3)$ & $4(26.6)$ & NS \\
\hline Present & $7(5.6)$ & $3(2.4)$ & & $3(12.0)$ & $1(6.6)$ & & $1(6.6)$ & $0(0)$ & \\
\hline \multicolumn{10}{|c|}{ Number of removed lymph nodes } \\
\hline$<5$ & $8(6.5)$ & $2(1.6)$ & NS & $2(8)$ & $1(6.6)$ & NS & $1(6.6)$ & $0(0)$ & NS \\
\hline $5-10$ & $13(10.5)$ & $12(9.7)$ & & $2(8)$ & $1(6.6)$ & & $2(13.3)$ & $0(0)$ & \\
\hline$>10$ & $51(41.6)$ & $37(30.1)$ & & $14(48.8)$ & $5(22)$ & & $8(53.4)$ & $4(26.6)$ & \\
\hline \multicolumn{10}{|c|}{ Lymph node metastasis } \\
\hline Absent & $42(38.2)$ & $34(27.6)$ & 0.022 & $7(28)$ & $3(12.0)$ & NS & $6(40)$ & $2(13.3)$ & 0.006 \\
\hline Present & $30(21.2)$ & $16(13)$ & & $11(44)$ & $4(16)$ & & $5(33.4)$ & $2(13.3)$ & \\
\hline \multicolumn{10}{|c|}{ Number of metastatic lymph nodes } \\
\hline$<5$ & $28(85.4)$ & $8(6.5)$ & 0.007 & $8(53.3)$ & $2(13.3)$ & NS & $3(20.0)$ & $1(6.6)$ & NS \\
\hline$>5$ & $8(6.5)$ & $2(1.6)$ & & $4(20.1)$ & $2(13.3)$ & & $2(13.3)$ & $1(6.6)$ & \\
\hline \multicolumn{10}{|c|}{ Lymph node pouch invasion } \\
\hline Absent & $10(8.3)$ & $2(1.6)$ & NS & $2(13.3)$ & $1(6.6)$ & NS & $7(66.7)$ & $3(20.0)$ & NS \\
\hline Present & $30(21.2)$ & $4(4.8)$ & & $6(40)$ & $6(40)$ & & $4(26.6)$ & $1(6.6)$ & \\
\hline \multicolumn{10}{|c|}{ Distant metastasis } \\
\hline Absent & - & - & - & $15(62)$ & $5(22)$ & NS & $0(0)$ & $0(0)$ & NS \\
\hline Present & & & & $2(8)$ & $2(8)$ & & $11(100)$ & $4(26.6)$ & \\
\hline \multicolumn{10}{|c|}{ Distant metastasis size $(\mathrm{mm})$} \\
\hline$<10$ & - & - & - & $2(8)$ & $0(0)$ & NS & $9(60)$ & $3(20.0)$ & NS \\
\hline$>10$ & & & & $2(8)$ & $0(0)$ & & $3(26.7)$ & $1(6.6)$ & \\
\hline \multicolumn{10}{|c|}{ Tumor deposits } \\
\hline Absent & - & - & - & $0(0)$ & $0(0)$ & NS & $9(60)$ & $2(13.3)$ & 0.052 \\
\hline Present & & & & $18(72)$ & $7(28)$ & & $2(13.3)$ & $2(13.3)$ & \\
\hline \multicolumn{10}{|c|}{$\begin{array}{l}\text { Inflammatory cell infiltrate in } \\
\text { the invasive front of tumor }\end{array}$} \\
\hline Absent & $8(6.5)$ & $7(5.6)$ & 0.002 & $2(8)$ & $1(6.6)$ & 0.042 & $2(13.3)$ & $1(6.6)$ & NS \\
\hline Weak & $31(25.2)$ & 23 (18.6) & & $6(24)$ & $4(16)$ & & $3(20.0)$ & $2(13.3)$ & \\
\hline Moderate & $17(14.2)$ & $15(12.1)$ & & $7(28)$ & $2(8)$ & & $5(33.6)$ & $1(6.6)$ & \\
\hline Strong & $16(13)$ & $6(4.8)$ & & $3(12.0)$ & $0(0)$ & & $1(6.6)$ & $0(0)$ & \\
\hline \multicolumn{10}{|c|}{$\begin{array}{l}\text { Inflammatory cell infiltrate in } \\
\text { the center of tumor mass }\end{array}$} \\
\hline Absent & $6(4.8)$ & $3(2.4)$ & 0.003 & $1(6.6)$ & $0(0)$ & NS & $1(6.6)$ & $0(0)$ & NS \\
\hline Weak & $21(19.5)$ & $33(24.5)$ & & $11(34.2)$ & $5(22)$ & & $9(60)$ & $3(20.0)$ & \\
\hline Moderate & $32(26)$ & $12(9.7)$ & & $3(12.0)$ & $1(6.6)$ & & $0(0)$ & $1(6.6)$ & \\
\hline Strong & $10(8.3)$ & $6(4.8)$ & & $3(12.0)$ & $1(6.6)$ & & $1(6.6)$ & $0(0)$ & \\
\hline
\end{tabular}

NS, not statistically significant; TILs, tumor infiltrating lymphocytes. 


\section{Acknowledgements}

Not applicable.

\section{Funding}

The author(s) received funding support from Medical University of Bialystok for this work (grant no. N/ST/ ZB/18/002/1194).

\section{Availability of data and materials}

The datasets used and/or analyzed during the present study are available from the corresponding author on reasonable request.

\section{Authors' contributions}

KJ prepared the conception and designed the study, collected the data, made the analysis and wrote the paper. MK performed the data analysis and provided suggestions for important content. WF and WK performed the microscopic examination. LKK interpreted the data. WF and WK reviewed the manuscript. All the authors approved the final version of manuscript.

\section{Ethics approval and consent to participate}

The study was performed in conformity with the Declaration of Helsinki for Human Experimentation and the protocol was approved by the Bioethics Committee of the Medical University of Bialystok (approval no. R-I-002/352/2016).

\section{Patient consent for publication}

Written informed consent was obtained from all participants.

\section{Competing interests}

The authors declare that they have no competing interests.

\section{References}

1. Jakóbisiak $M$ and Lasek W: Immunologia nowotworów. In: Immunologia. Gołąb J, Jakóbisiak M, Lasek W and Stokłosa T (eds). 5th Edition. Wydawnictwo Naukowe PWN, Warszawa, pp478-484, 2007.

2. Kuss I, Hathaway B, Ferris RL, Gooding W and Whiteside TL: Decreased absolute counts of T lymphocyte subsets and their relation to disease in squamous cell carcinoma of the head and neck. Clin Cancer Res 10: 3755-3762, 2004.

3. Edge SB, Byrd D, Compton CC, Fritz AG, Greene F and Trotti A: American Joint Committee On Cancer. AJCC Cancer Staging Manual. 7th edition. Springer, New York, NY, 2010.

4. Kumar S, Skeen MJ, Adiri Y, Yoon H, Vezys VD, Lukacher AE, Evavold BD, Ziegler HK and Boss JM: Acytokine promoter/yellow fluorescent protein reporter transgene serves as an early activation marker of lymphocyte subsets. Cell Immunol 237: 131-140, 2005.

5. Kwak Y, Koh J, Kim DW, Kang SB, Kim WH and Lee HS: Immunoscore encompassing $\mathrm{CD}^{+}$and $\mathrm{CD}^{+} \mathrm{T}$ cell densities in distant metastasis is a robust prognostic marker for advanced colorectal cancer. Oncotarget 7: 81778-81790, 2016.

6. Quatromoni JG, Wang Y, Vo DD, Morris LF, Jazirehi AR, McBride W, Chatila T, Koya RC and Economou JS: T cell receptor (TCR)-transgenic CD8 lymphocytes rendered insensitive to transforming growth factor beta (TGF $\beta$ ) signaling mediate superior tumor regression in an animal model of adoptive cell therapy. J Transl Med 10: 127, 2012.
7. Tauriello DV, Calon A, Lonardo E and Batlle E: Determinants of metastatic competency in colorectal cancer. Mol Oncol 11: 97-119, 2017.

8. Ramnath N, Tan D, Li Q, Hylander BL, Bogner P, Ryes L and Ferrone S: Is downregulation of MHC class I antigen expression in human non-small cell lung cancer associated with prolonged survival? Cancer Immunol Immunother 55: 891-899, 2006.

9. Salvi S, Fontana V, Boccardo S, Merlo DF, Margallo E, Laurent S, Morabito A, Rijavec E, Dal Bello MG, Mora M, et al: Evaluation of CTLA-4 expression and relevance as a novel prognostic factor in patients with non-small cell lung cancer. Cancer Immunol Immunother 61: 1463-1472, 2012.

10. Oken MM, Creech RH, Tormey DC, Horton J, Davis TE, McFadden ET and Carbone PP: Toxicity and response criteria of the eastern cooperative oncology group. Am J Clin Oncol 5: 649-655, 1982.

11. Hamilton SR and Aaltonen LA: Tumours of the colon and rectum In: World health organization classification of tumours. Pathology and genetics of tumours of the digestive system. IARC Press, Lyon, p.103-104, 2000.

12. Therasse P, Arbuck SG, Eisenhauer EA, Wanders J, Kaplan RS Rubinstein L, Verweij J, Van Glabbeke M, Van Oosterom AT, Christian MC and Gwyther SG: New guidelines to evaluate the response to treatment in solid tumors. European organization for research and treatment of cancer, national cancer institute of the united states, national cancer institute of Canada. J Natl Cancer Inst 92: 205-216, 2000.

13. Lin Q, Wei Y, Ren L, Zhong Y, Qin C, Zheng P, Xu P, Zhu D, $\mathrm{Ji} \mathrm{M}$ and $\mathrm{Xu} \mathrm{J}$ : Tumor deposit is a poor prognostic indicator in patients who underwent simultaneous resection for synchronous colorectal liver metastases. Onco Targets Ther 8: 233-240, 2015.

14. Song YX, Gao P, Wang ZN, Liang JW, Sun Z, Wang MX, Dong YX, Wang XF and Xu HM: Can the tumor deposits be counted as metastatic lymph nodes in the UICC TNM staging system for colorectal cancer? PLoS One 7: e34087, 2012.

15. Klintrup K, Mäkinen JM, Kauppila S, Väre PO, Melkko J, Tuominen H, Tuppurainen K, Mäkelä J, Karttunen TJ and Mäkinen MJ: Inflammation and prognosis in colorectal cancer. Eur J Cancer 41: 2645-2654, 2005.

16. Salgado R, Denkert C, Demaria S, Sirtaine N, Klauschen F, Pruneri G, Wienert S, Van den Eynden G, Baehner FL, Penault-Llorca F, et al: The evaluation of tumor-infiltrating lymphocytes (TILs) in breast cancer: Recommendations by an international TILs working group 2014. Ann Oncol 26: 259-271, 2015.

17. Iseki Y, Shibutani M, Maeda K, Nagahara H, Fukuoka T, Matsutani S, Kashiwagi S, Tanaka H, Hirakawa K and Ohira M: A new method for evaluating tumor-infiltrating lymphocytes (TILs) in colorectal cancer using hematoxylin and eosin (H-E)-stained tumor sections. PLoS One 13: e0192744, 2018

18. Perez RO, Habr-Gama A, dos Santos RM, Proscurshim I, Campos FG, Rawet V, Kiss D and Cecconello I: Peritumoral inflammatory infiltrate is not a prognostic factor in distal rectal cancer following neoadjuvant chemoradiation therapy. J Gastrointest Surg 11: 1534-1540, 2007.

19. Li Y, Liang L, Dai W, Cai G, Xu Y, Li X, Li Q and Cai S: Prognostic impact of programed cell death-1 (PD-1) and PD-ligand 1 (PD-L1) expression in cancer cells and tumor infiltrating lymphocytes in colorectal cancer. Mol Cancer 15: 55, 2016.

20. Radzikowski C, Opolski A and Wietrzyk J: Postęp w badaniach procesu wzrostu inwazyjnego i przerzutowania. Nowotwory 53: 57-65, 2002 (In Polish).

21. Galon J, Costes A, Sanchez-Cabo F, Kirilovsky A, Mlecnik B, Lagorce-Pagès C, Tosolini M, Camus M, Berger A, Wind P, et al: Type, density, and location of immune cells within human colorectal tumors predict clinical outcome. Science 313: 1960-1964, 2006.

22. LeBoit G, Burg G Weedon D and Sarasin A (eds): Pathology and Genetics of Skin Tumours. IARC Press, Lyon, 2005.

23. Huh JW, Lee JH and Kim HR: Prognostic significance of tumor-infiltrating lymphocytes for patients with colorectal cancer. Arch Surg 147: 366-372, 2012.

24. Pagès F, Galon J and Fridman WH: The essential role of the in situ immune reaction in human colorectal cancer. J Leukoc Biol 84: 981-987, 2008.

25. Pagès F, Berger A, Camus M, Sanchez-Cabo F, Costes A, Molidor R, Mlecnik B, Kirilovsky A, Nilsson M, Damotte D, et al: Effector memory $\mathrm{T}$ cells, early metastasis, and survival in colorectal cancer. N Engl J Med 353: 2654-2666, 2005. 
26. Mlecnik B, Tosolini M, Kirilovsky A, Berger A, Bindea G Meatchi T, Bruneval P, Trajanoski Z, Fridman WH, Pagès F and Galon J: Histopathologic-based prognostic factors of colorectal cancers are associated with the state of the local immune reaction. J Clin Oncol 29: 610-618, 2011.

27. Buckowitz A, Knaebel HP, Benner A, Bläker H, Gebert J, Kienle P, von Knebel Doeberitz M and Kloor M: Microsatellite instability in colorectal cancer is associated with local lymphocyte infiltration and low frequency of distant metastases. Br J Cancer 9: 1746-1753, 2005.

28. Youssef MM, Paish EC, Murray JC, Farag NM, Saleh K and Ellis IO: Tumor infiltrating T lymphocytes and apoptosis in colorectal cancer. Egypt J Immunol 22: 19-28, 2015.

29. Phillips SM, Banerjea A, Feakins R, Li SR, Bustin SA and Dorudi S: Tumour-infiltrating lymphocytes in colorectal cancer with microsatellite instability are activated and cytotoxic. Br J Surg 91: 469-475, 2004.

30. Salama P, Phillips M, Grieu F, Morris M, Zeps N, Joseph D, Platell $\mathrm{C}$ and Iacopetta BJ: Tumor-infiltrating FOXP $3^{+} \mathrm{T}$ regulatory cells show strong prognostic significance in colorectal cancer. Clin Oncol 27: 186-192, 2009.

31. Ohtani H: Focus on TILs: Prognostic significance of tumor infiltrating lymphocytes in human colorectal cancer. Cancer Immun 7: 4, 2007.

32. Qi QH, Wang T, Mao Y and Hua D: Prognostic significance of tumor deposits in patients with stage III colon cancer. Zhonghua Zhong Liu Za Zhi 38: 784-789, 2016 (In Chinese).

33. Wei X, Qiu MZ, Zhou XY, He MM, Luo HY, Wang FH, Zhang DS, Li YH and Xu RH: The clinicopathologic relevance and prognostic value of tumor deposits and the applicability of N1c category in rectal cancer with preoperative radiotherapy. Oncotarget 7: 75094-75103, 2016.
34. Gopal P, Lu P, Ayers GD, Herline AJ and Washington MK: Tumor deposits in rectal adenocarcinoma after neoadjuvant chemoradiation are associated with poor prognosis Mod Pathol 27: 1281-1287, 2014.

35. Lee WS, Kang M, Baek JH, Lee JI and Ha SY: Clinical impact of tumor-infiltrating lymphocytes for survival in curatively resected stage IV colon cancer with isolated liver or lung metastasis. Ann Surg Oncol 20: 697-702, 2013.

36. Schweiger T, Berghoff AS, Glogner C, Glueck O, Rajky O, Traxler D, Birner P, Preusser M, Klepetko W and Hoetzenecker K: Tumor-infiltrating lymphocyte subsets and tertiary lymphoid structures in pulmonary metastases from colorectal cancer. Clin Exp Metastasis 33: 727-739, 2016.

37. Halama N, Michel S, Kloor M, Zoernig I, Benner A, Spille A, Pommerencke T, von Knebel DM, Folprecht G, Luber B, et al: Localization and density of immune cells in the invasive margin of human colorectal cancer liver metastases are prognostic for response to chemotherapy. Cancer Res 71: 5670-5677, 2011.

38. Morris M, Platell C and Iacopetta B: Tumor-infiltrating lymphocytes and perforation in colon cancer predict positive response to 5-fluorouracil chemotherapy. Clin Cancer Res 14: 1413-1417, 2008.

(i) $(-)$ This work is licensed under a Creative Commons Attribution-NonCommercial-NoDerivatives 4.0 International (CC BY-NC-ND 4.0) License. 